\title{
An Appropriate Past for Renaissance Portugal: André de Resende and the City of Évora
}

\author{
Nuno Senos
}

\section{$1 \quad$ An Appropriate Past for Portugal}

From the mid-fifteenth century, in the period that we call the Renaissance, various Portuguese literati, artists, and thinkers-at-large began to ponder their country's past. The predominant lens through which most of us have been taught to look at the Renaissance shows that such historical roots were sought in Roman times. However, as the present volume makes clear, the relationship between the past and the men at the dawn of the early modern age was a more nuanced and complex one.

In this chapter, I shall look at this relationship through the case of Évora, a former Roman city and the seat of a palaeo-Christian bishopric (dating back at least to the early fourth century), which had perished during the times of the Muslim domain over the Iberian Peninsula (from 711 AD onwards) but had been revived during the Reconquista, after which point the city (conquered by Christian troops in 1165) became one of the crown's favourites, and therefore a favourite of the aristocracy as well. ${ }^{1}$ The combination of all of these factors granted Évora a very central place in the Renaissance construction of a past for Portugal.

Of paramount importance in such an endeavour was the work of Évoraborn humanist André de Resende (ca. 1500-1573), which provides a fine example of the intricacies involved. ${ }^{2}$ Resende was educated in Alcalá de Henares and Salamanca, and he spent most of the first three decades of his life

1 The bibliography on Évora in the Renaissance is vast. See, for instance, Espanca T., Évora (Lisbon: 1993); and Branco M.C., "Renascimento, Maneirismo e Estilo Chão em Évora", in Cunha M.S. da (ed.), Do Mundo Antigo aos Novos Mundos. Humanismo, Classicismo e Notícias dos Descobrimentos em Évora (1516-1624) (Lisbon: 1998) 219-247.

2 Most data on the life and work of André de Resende can be found in Ferreira F.L., "Notícias da vida de André de Resende", Arquivo Histórico Português 7 (1909) 393-417; 8 (1910) 62-69, 161-184, 338-366; 9 (1914) 177-334. Interesting data and analysis are also in the introductory study of Resende André de, Oração de Sapiência (Oratio pro Rostris), ed. A. Moreira de Sá (Lisbon: 1956).

(C) NUNO SENOS, 2019 | DOI:10.1163/9789004378216_007

This is an open access chapter distributed under the terms of the prevailing CC-BY-NC-ND License 
travelling through Spain, the south of France, Leuven (where he published his first books, including an Erasmi encomium), Paris (where he studied Greek), and Brussels (where he worked for the Portuguese ambassador to the court of Charles v). He was therefore a cultivated, well-rounded, and widely travelled man when he settled back in his home town in the 1530s, staying there until his death almost five decades later. He devoted himself to the study of the city's past, publishing his História da antiguidade da cidade de Évora (History of the Antiquity of the City of Évora) in 1553, later preparing a revised, second edition, which came out posthumously in $1576 .^{3}$

An accomplished Latinist and an admirer of ancient Rome, Resende was at the same time invested in the creation of a national history, a concern that brought about some difficulties, as we shall see. Furthermore, he was a devout Catholic (a Dominican friar, in fact, for a period of his life) who was equally and perhaps even more interested in the Christian history of his country and his city. The reconciliation of these three concerns required some rhetorical gymnastics that Resende navigated with ease but that today requires analysis. While this chapter will not go into detail on all of his points of interest, it is important to make some preliminary remarks in this respect before we focus on the efforts made to create a Roman past for Évora (and, by extension, for Portugal), which included the fabrication of fakes, where they were deemed necessary.

\section{National Identity}

When writing about Évora, Resende is consistently concerned with the creation of a national history - in other words, a political and cultural Portuguese identity grounded in the past. He begins by trying to identify a founder for his city, a task which he deemed impossible and quickly abandoned. Thus, the history of Évora that he is capable of recuperating truly begins with the Romans. As soon as he starts writing about the Romans, however, the difficulties of the process become apparent. For instance, the fact that the territory that was Portugal in the sixteenth century did not correspond to any Roman administrative district was somewhat problematic. There was no Latin word for the name of the country itself, so Resende, as well as all his fellow authors, referred to Portugal as Lusitania (a practice that persists to this day - 'luso'

3 Resende André de, História da antiguidade da cidade de Évora (Évora, André de Burgos: 1553). For the purposes of this chapter, I shall use the modern edition included in Resende André de, Obras Portuguesas, ed. J.P. Tavares (Lisbon: 1963). 
remains the prefix to denote Portuguese), one of the Roman circumscriptions for Iberia that encompassed a part (but only a part) of early modern Portugal (as well as a part of Spain). Thus, a Latin name created by the Romans was consecrated to refer to a territory that (supposedly) pre-existed the Roman settlement in Iberia.

Referring as little as possible to geography, Resende posited a sort of a cultural Lusitania, which would have existed before the Romans and survived beyond Roman times in the form of Portugal. In his book on Évora, Resende refrains from detailing what cultural Lusitania may have been, a shortcoming he seems to have become aware of later and that he tried to correct in his De Antiquitatibus Lusitaniae, a text he left unfinished and which was posthumously completed, and then published in $1593 \cdot{ }^{4}$ In this book the Lusitanians are mostly characterized as a brave, indomitable people that did their best (although they eventually failed) to resist the attacks of the Romans.

What he has to say about the Roman governors of Lusitania is short (in both books) and not particularly complimentary, but perhaps the most interesting aspect of his historical discourse is that it is not the Romans who are the heroes of his history, but rather those who (at least in his eye) resisted the Roman takeover of the Iberian Peninsula. Viriato, still celebrated in both Portugal and Spain as a founding hero, a leader of a pre-Roman Iberian tribe that Resende believed to have been born in the Portuguese part of Lusitania, is his first hero - 'a great Lusitanian', he claims. ${ }^{5}$ As a humanist Resende relied on a vast plethora of classical authors to reconstruct Viriato's story, but the ultimate result is a sort of primal Portuguese-before-Portugal, the first general of a protoindependent country that would come into being over a thousand years later.

Resende spends even more pages celebrating another anti-Roman hero (or so he constructs him), Quintus Sertorius, who was in fact a Roman general who had been placed in the Iberian Peninsula in 83 BC. Sertorius established an alliance with the Lusitanians against Rome, where Sulla was in command. At first successful in his resistance against Sulla, he eventually started losing ground and was finally killed by his own men. Sertorius was a favourite of the men of the Portuguese renaissance. In their writings, the intricacies of his opposition to a specific Roman regime - that of Sulla - were transformed into a form of local resistance against a foreign oppressor - Rome - and thus a symbol of Lusitanian independence and bravery in its defence.

4 Resende André de, De antiquitatibus Lusitaniae (Évora, Martim de Burgos: 1593). For the purposes of this chapter I shall use the following edition: Resende André de, As antiguidades da Lusitânia, ed. R.M. Rosado Fernandes (Lisbon: 1996).

5 'grande Lusitano', Resende, Obras Portuguesas 14. 
The gap between Viriato's and Sertorius' time and that of the Christian conquest of Évora in the context of the Reconquista (1165 AD), a period of over 1,00o years, was smoothly shortened and sometimes altogether obliterated in Resende's narrative; no reference whatsoever is made to the almost 500 years during which Iberia was under Islamic rule. In Resende's discourse, the first kings of medieval, Reconquista Portugal were indeed rebuilding pre-Roman Lusitania. ${ }^{6}$

The case of Sertorius is particularly telling since he was believed to have lived in Évora, which he chose not only because of its strategic position, 'in the middle of Lusitania,, ${ }^{7}$ but also as a form of recognition of the city's support for his (supposedly) anti-Roman cause. An inscription mentioning Sertorius was found near the ruins of a set of Roman thermae, and that was used to identify the house in which he had lived and which was henceforth and to this day is known as Sertorius' Palace. According to Resende, the inscription read as follows:

LARIB. ${ }^{8}$ PRO SALVTATE ET INCOLVMITATE DOMUS $\quad{ }^{9}{ }^{9}$ SERTORII COMPETALIB. $^{10}$ LUdOS ET EPULUM VICINEIS ${ }^{11}$ JUNIA DONACE DOMESTICA EJVS ET Q. SERTOR. ${ }^{12}$ HERMES, Q. ${ }^{13}$ SERTOR. ${ }^{14}$ CEPALO, Q. ${ }^{15}$ SERTOR. ${ }^{16}$ ANTEROS LIBERTI.

In honour of the gods of the house. For the health and safety of the house of Quintus Sertorius, financed Junia Donace, his slave born in his house, and his freedmen Quintus Sertorius Hermes, Quintus Sertorius Cepalo and Quintus Sertorius Anteros, public games and a meal for the neighbourhood, held on the feast of the Compitalia. ${ }^{17}$

$6 \quad$ This is still by and large the rough version of the early history of Portugal that is taught to students in primary schools in the country.

7 'em meio de Lusitânia', Resende, Obras portuguesas 16.

$8=$ LARIB $<$ VS $>$. I am grateful to Karl Enenkel for the annotation and the English translation of this inscription.

9 =QVINTI.

$10=$ COMPITALIB $<$ VS $>$.

11 =VICINIS.

$12=$ SERTOR $<$ IVS $>$.

$13=$ QVINTVS.

$14=$ SERTOR $<$ IVS $>$.

15 =QVINTVS.

16 See note 14.

17 Resende, Historia da antiguidade $7-8$, provides the transcription and the following Portuguese translation: 'Por saude \& stabilidade da casa de Quinto Sertorio Iunia Donace 
The Roman general was furthermore said to be responsible for the construction of the city's wall, sections of which were (and remain) still visible, and for that of its aqueduct. Sertorius was therefore a particularly relevant figure for the history of Portugal at large and for that of Évora in particular.

As it turns out, most of this is a fabrication. Sertorius did exist - he himself is not the fabrication here - but he did not side with the Lusitanians against the Romans; he engaged their support in a Roman civil war against Sulla. He had nothing to do with a local sense of independence, even less with the idea of a Portuguese independence; he simply wanted to replace those in power in Rome. He may well have lived in Évora, but such a claim lacks historical grounding because no primary source places Sertorius anywhere near Évora, where he may well have never set foot. The abovementioned inscription mentions a Sertorius but not necessarily the one Resende was interested in. And finally, today there is relative consensus that the city wall was probably built in the third century AD, and therefore long after Sertorius' death. The aqueduct, in turn, requires more discussion, and I will come back to it later in this chapter.

Resende was not the first to propose several of these ideas, but his contribution was certainly significant for their consolidation. The fact that they were grounded on the authority of ancient authors and, perhaps even more importantly, on that of inscriptions certainly contributed to the weight of his arguments. Conversely, the shortcomings of Resende's approach did not seem to have raised many eyebrows (a notorious exception will be mentioned later) until modern historians looked into the matter. In any case, this (successful) attempt at constructing a Portuguese past for Évora and for Portugal exemplifies a certain way of looking at history, guided by the clear concern for creating a national identity.

Having established a Roman past for the city, Resende devotes most of the rest of his book to the Christian roots of Évora. His main concern is to prove that Évora is one of the oldest Christian cities in Iberia, which he does, for instance, by referring to the tradition of Saint Manços as the evangelizer of the city. Manços was the disciple of an apostle, Saint James, and he was generally

sua domestica, \& Quinto Sertorio Hermes, \& Quinto Sertorio Cepalo, \& Quinto Sertorio Anteros, seus libertos, aa honra dos deoses Lares, en ho dia da festa chamada Cõpitalia, fezeron jogos públicos \& deeran conuite a todos os vizinhos'. 
regarded to have been the first bishop of Évora: two degrees of separation from Christ himself made for a very distinguished pedigree indeed. Manços' bodily remains had been buried in a church built for the purpose. During times of Arabic invasion, the saint's body was taken north, to Sahagun, in Asturias, where it was safely kept. Immediately after the Reconquista of the city, the bishopric was re-established and a cathedral commissioned. One of its chapels was dedicated to the saint, and it was under this chapel that the founding stone of the new building was placed, in 1186. The story of this saint was therefore known before Resende, and he was keen on going over it in his book and insisting upon the need to further dignify this devotion in the city. Of the church in which the saint was originally buried, which was dedicated to him, only a tower remained, and Resende vehemently deplored the ruinous state in which it was poorly kept. This is an example of how interest in the Christian past would eventually influence the history of renaissance architecture in Portugal, as in 1591 a campaign was started to renovate the remains of the tower and to enlarge them into a whole church, to which some relics of the saint were returned. ${ }^{18}$

A proper Christian past also requires early martyrs from Roman times. Évora, Resende argued, had three of them: the siblings Vincent, Sabina, and Cristeta. Like that of Manços, the history of these three martyrs relied upon rather thin evidence, but for Resende it was important to prove that they were natives of the city and that they had been martyred in the time of Emperor Diocletian, thus showing that Évora had been Christian since the religion's very early days. Both claims were disputed, and Portuguese and Spanish intellectuals had different opinions about them. The point of contention was whether the three siblings were natives of Évora or Talavera, and therefore which of the two cities could use them to support their claims to old Christian roots. The fact that their relics had also been transferred north in Arabic times and were now sumptuously celebrated in their own church in Ávila favoured the Spanish side of the dispute. Nevertheless, in a long letter written in 1567 to a man from Toledo called Quevedo, Resende argues his case along the same lines he had used for his defence earlier in his history of Évora and denoting the same concerns. ${ }^{19}$ Relevant to the history of architecture is that in Évora only a small, dilapidated chapel was devoted to the martyrs, and Resende also argued that it should be replaced with a more dignified one. In the 1560 s,

\footnotetext{
18 Cf. Espanca Túlio, Inventário Artístico de Portugal. VII. Concelho de Évora (Lisbon: 1966), vol. 1, 373-375.

Resende André de, Carta a Bartolomeu de Quevedo, ed. V.S. Pereira (Coimbra: 1979).
} 


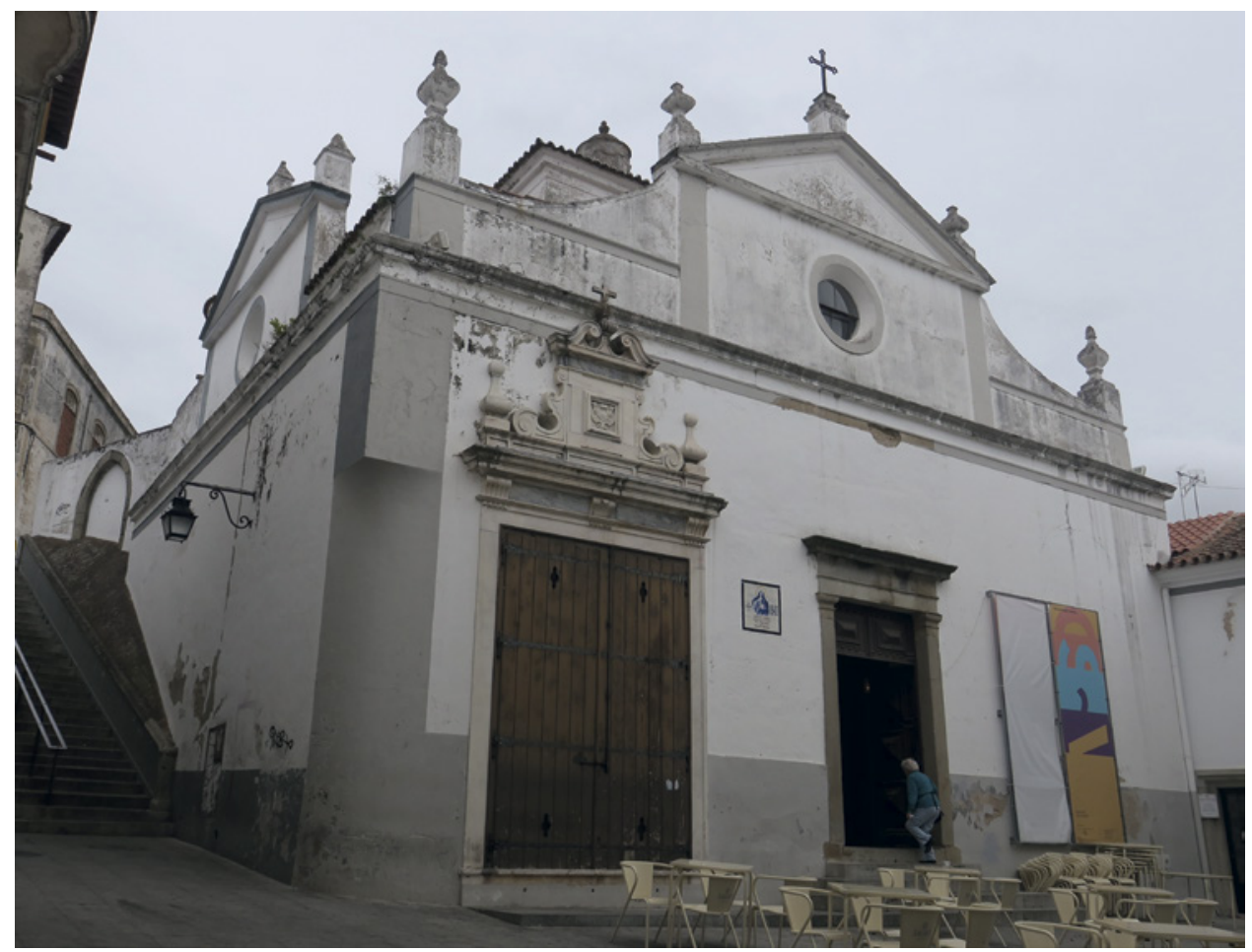

FIGURE 5.1 Church of Saint Vincent, Évora IMAGE () NUNO SENOS

under his own initiative and financial support, a new church was finally built, which was dedicated to the three martyrs (and popularly known as the church of Saint Vincent) [Fig. 5.1], and Resende could proudly report to his Spanish interlocutor that the new church was 'artistically adequate and [had] excellent dimensions. ${ }^{20}$ That it was a centralized building and thus particularly suitable for a martyrium could well have been Resende's own idea. ${ }^{21}$ Once again, concern about a Christian past played a role in the architectural history of the country.

From the point of view of the construction of the past, Resende's approach of the Christian past does not differ much from his fabrication of a national identity: historical sources were used with some liberty in order to prove

20 'Artisticamente cuidado e com excelentes dimensões', Resende, Carta 102.

21 On this church, see Espanca T., "Fundação e Evolução Histórica da Igreja dos Mártires de Évora”, A Cidade de Évora (1st series) 29-30 (1949) 472-483. 
the points that mattered the most to him. The past was important mostly to establish that Portugal itself had a very old cultural identity and that that identity was, first and foremost, Christian. The church of the three martyrs functioned as a perfect synthesis of all these concerns: it was built in the shape of a Greek cross, used the classical orders (Doric in this case) to celebrate early 'Portuguese' martyrs, and somewhat brought together the Christian and the Roman pasts, successfully intertwining the prestige of classical times with that of a strongly rooted religion.

While these concerns can be detected in other authors of the period, it must also be kept in mind that these were men (and very few women) who admired the Roman past immensely. They had been educated in Latin, a language in which they corresponded and published; they had read the classics and revered them. For them, the weight of the Roman written word, either published or inscribed, was the ultimate source of historical legitimacy and it was to it that they turned whenever authoritative data were needed.

The architectural remains of the Roman past were treated in a different, somewhat puzzling way. It is most surprising to reflect upon the role played (or not played, as I shall argue) by the Roman temple of Évora [Fig. 5.2]. Built in the first century of our era, it was the temple of the city's forum, a location whose centrality was maintained in medieval times. In fact, it was right next to this temple (although it did not replace it) that the twelfth-century cathedral was built, and then its cloister, and eventually the adjoining bishop's palace. Throughout this process, destructive in nature in so many other respects, the imposing Roman remains were spared, and they have come to us as the most spectacular Roman ruins in the country. Therefore, the men and women of the Portuguese renaissance, those who commissioned buildings, those who designed and erected them, those who wrote about them - they all had this magnificent ruin as their neighbour from which to draw inspiration. If they were interested in classical architecture, they did not have to limit themselves to the many prints that circulated depicting the most famous Italian buildings of antiquity; they could look at their own.

It is therefore surprising to realize that the architectural past that the early Portuguese renaissance was trying to bring back to life does not seem to bear much relationship to the one Roman building that survived in the country. The fanciful fluted columns and the ornate Corinthian capitals of Évora's temple did not appeal to the architects and/or patrons of the 


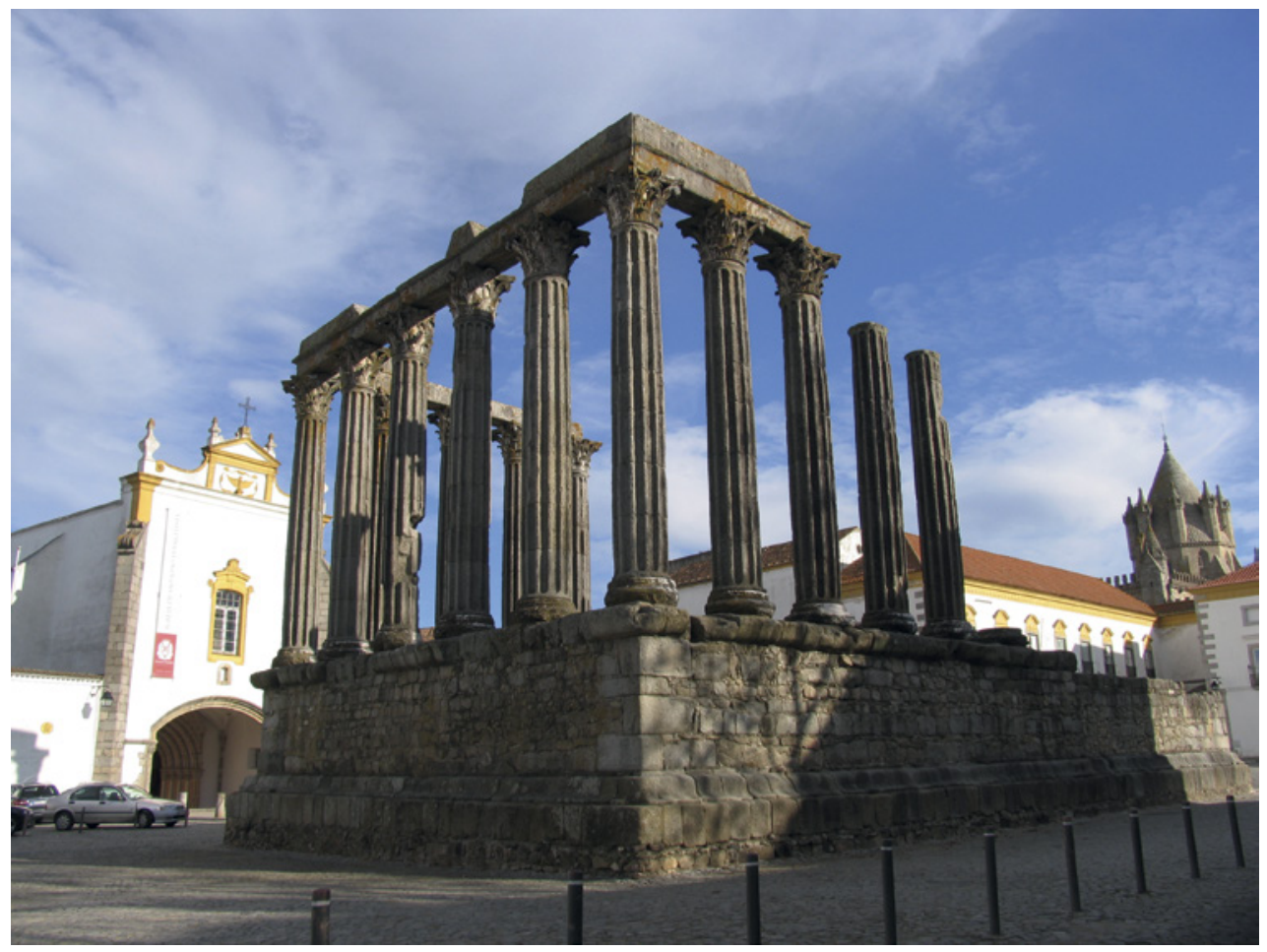

FIGURE 5.2 The Roman temple of Évora IMAGE (C) NUNO SENOS

period. In fact, when they were looking for Roman (or Roman-inspired) architectural solutions it was not to Évora that they turned their attention, but rather to printed images that circulated abundantly or to the visual experience brought to Portugal by artists coming mostly from France, Flanders, or Spain.

If one considers the earliest examples of ancient-looking ornamentation used in Portugal - described in the documents as ao romano (in Roman style) dating back to the 1510 s, such as the portal of the cathedral of Lamego or the cloister of the Hieronimyte monastery in Lisbon [Fig. 5.3], it becomes very clear that Évora's temple was not the source of inspiration that shaped them. The same conclusion is reached when considering constructions closer to Évora, such as the portal of the church of Arronches or that of the Clarisses from Vila Viçosa, whose authors (even if not always yet identifiable) are likely to have visited Évora. Even those who built the earliest renaissance churches in the city proper [Fig. 5.4], sometimes using the same local granite [Fig. 5.5], 


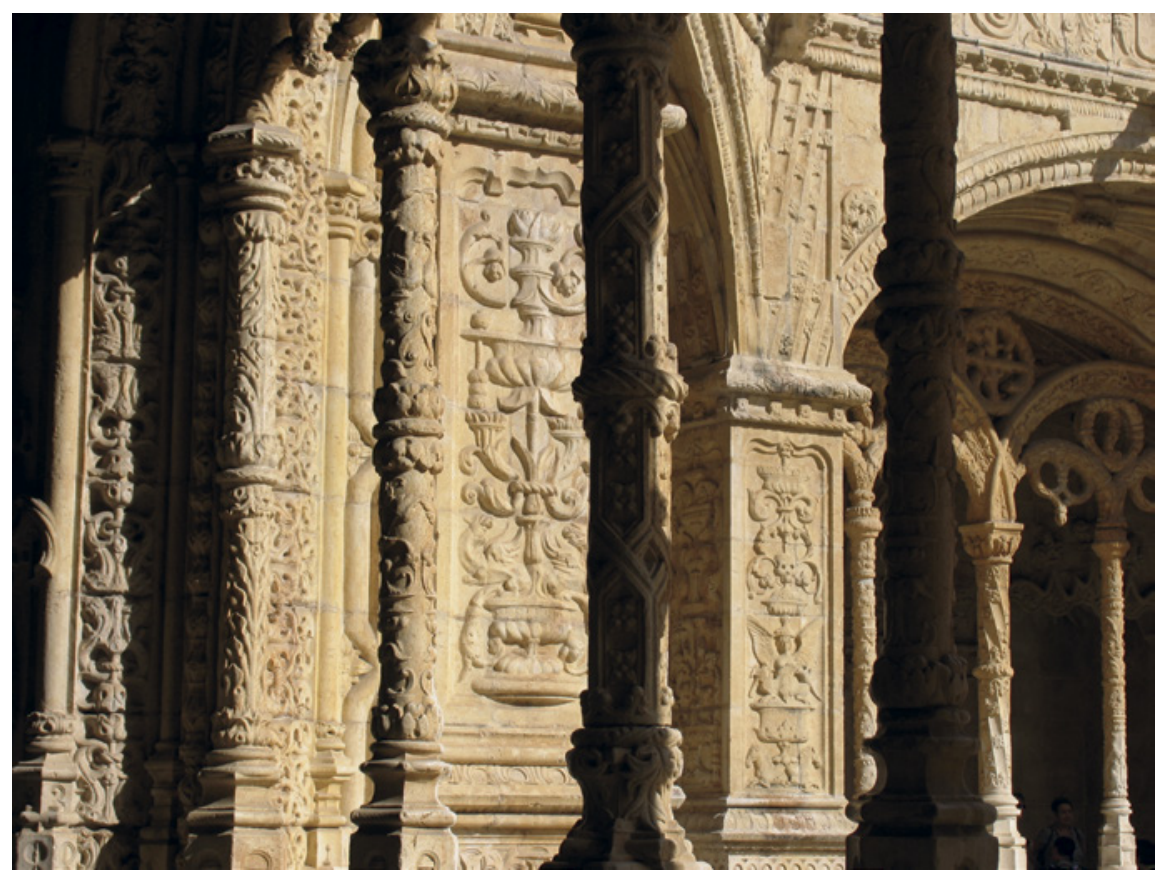

FIGURE 5.3 Detail of the cloister of the monastery of Jerónimos, Lisbon IMAGE (C) NUNO SENOS

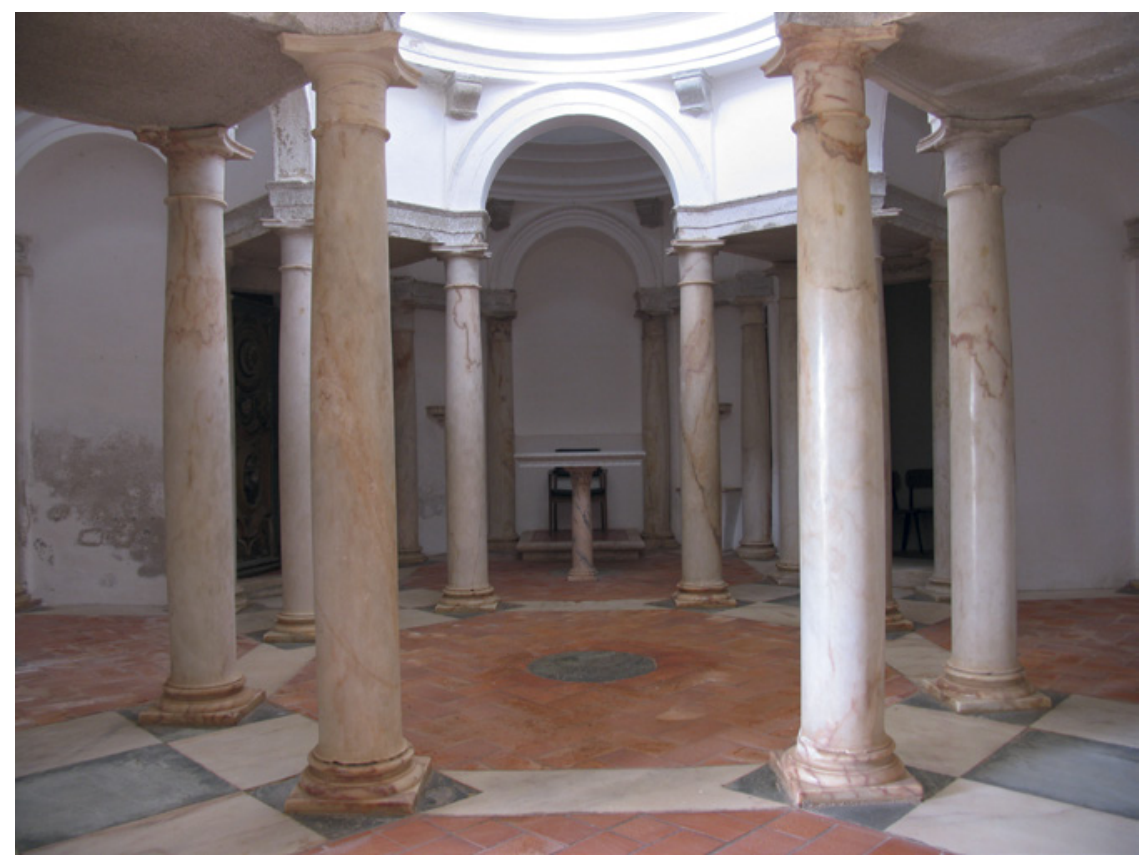

FIGURE 5.4 Interior of the church of Valverde near Évora IMAGE (C) NUNO SENOS 


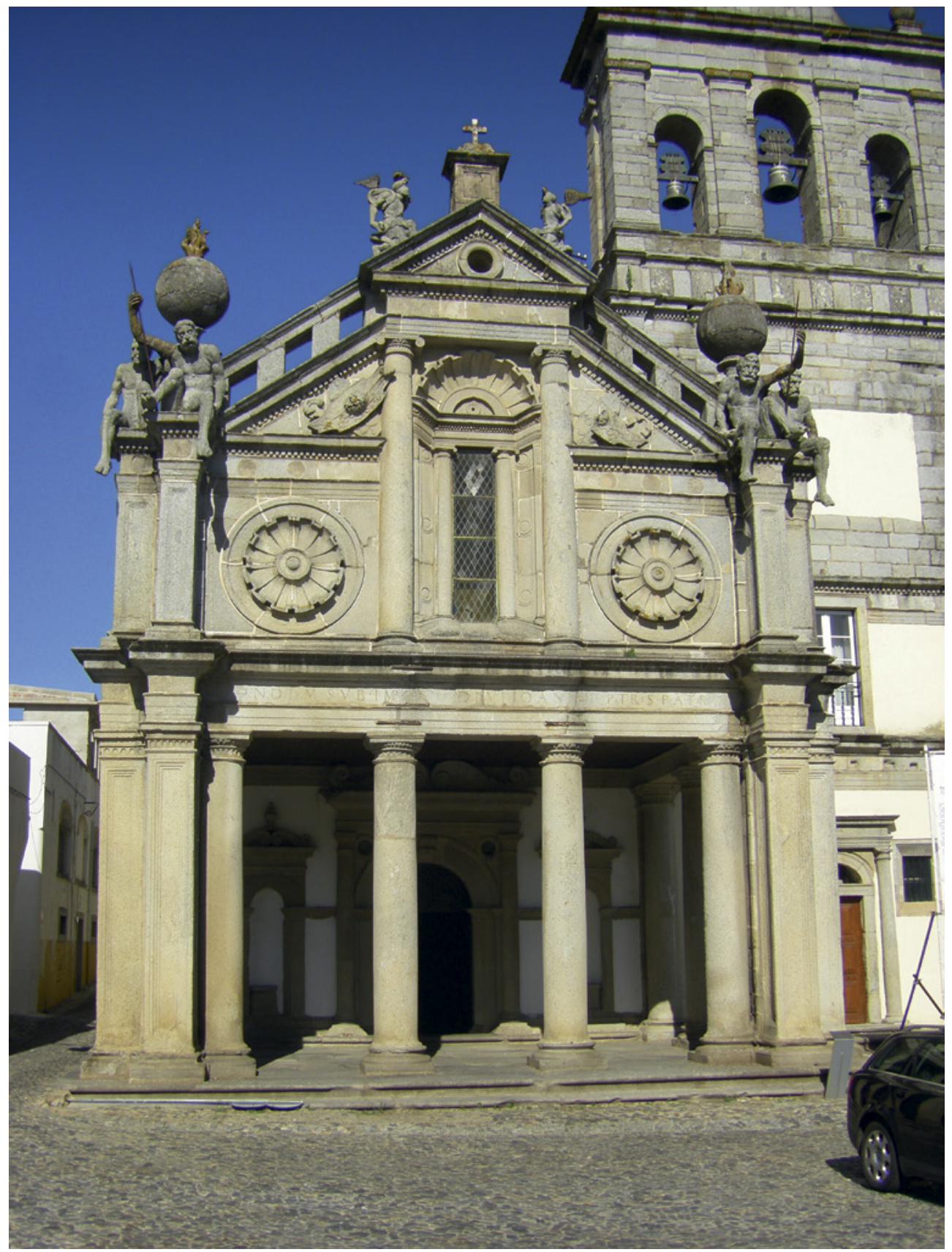

FIGURE 5.5 Façade of the church of Graça, Évora IMAGE (C) NUNO SENOS 
just a few steps away from the Roman temple - even they were not looking at the actual ancient remain they had at hand.

The explanation for this seemingly strange phenomenon lies in part, but only in part, in the medieval fate of the Roman temple. In fact, the temple was spared the dismantling or the total destruction that happened to so many other buildings during the complex process of the fall of the Western Roman Empire. It did, nevertheless, lose its functionality to become a pointless, incomprehensible, and useless ruin sitting at the very centre of the city. At least as early as the fourteenth century, the space between the surviving columns of the temple had been walled-in, more walls had been built where columns were missing, and crenellation had been added to the full perimeter of the building, which was subsequently reused as the city's butchery [Fig. 5.6].

It was as such that the building remained until the 1840 s, when the municipality decided to close down the butchery and restore whatever was left of the original temple while clearing the surrounding area in order to monumentalize it. Promptly, the duchess of Palmela presented the city with her own adjacent property for demolition, including a building whose walls were attached to those of the butchery. ${ }^{22}$ There is no record of what the said building may have looked like or how it connected to the ruin, but this must have contributed to its invisibility in medieval and early modern times. Invisibility, in fact, explains why Resende refers to it as 'a handsome portico with Corinthian columns' in the only words that he (or any other renaissance author) dedicates to the Roman remain whose original function had already been forgotten. ${ }^{23}$

\section{The Roman Past: The Aqueduct}

In spite of this peculiar case, other routes were taken to fabricate a Roman past for Évora. One of the earlier attempts may have been linked to the city's bishop (between 1485 and 1522) Afonso de Portugal, a natural son of the duke of Bragança, who was educated in Salamanca and was an eager collector of Roman inscriptions. ${ }^{24}$ When King Manuel came to power in 1495 he

\footnotetext{
22 Leal J.C., Giuseppe Cinatti (1808-1879). Percurso e Obra, MA thesis (Lisbon: 1996) 283-285.

23 'Um belo pórtico de colunas coríntias', Resende, Carta 101.

24 Caetano J.O., "Sombras e Alguma Luz Sobre o Bispo D. Afonso de Portugal", Cenáculo. Boletim On Line do Museu de Évora 2 (2007) 3-24.
} 


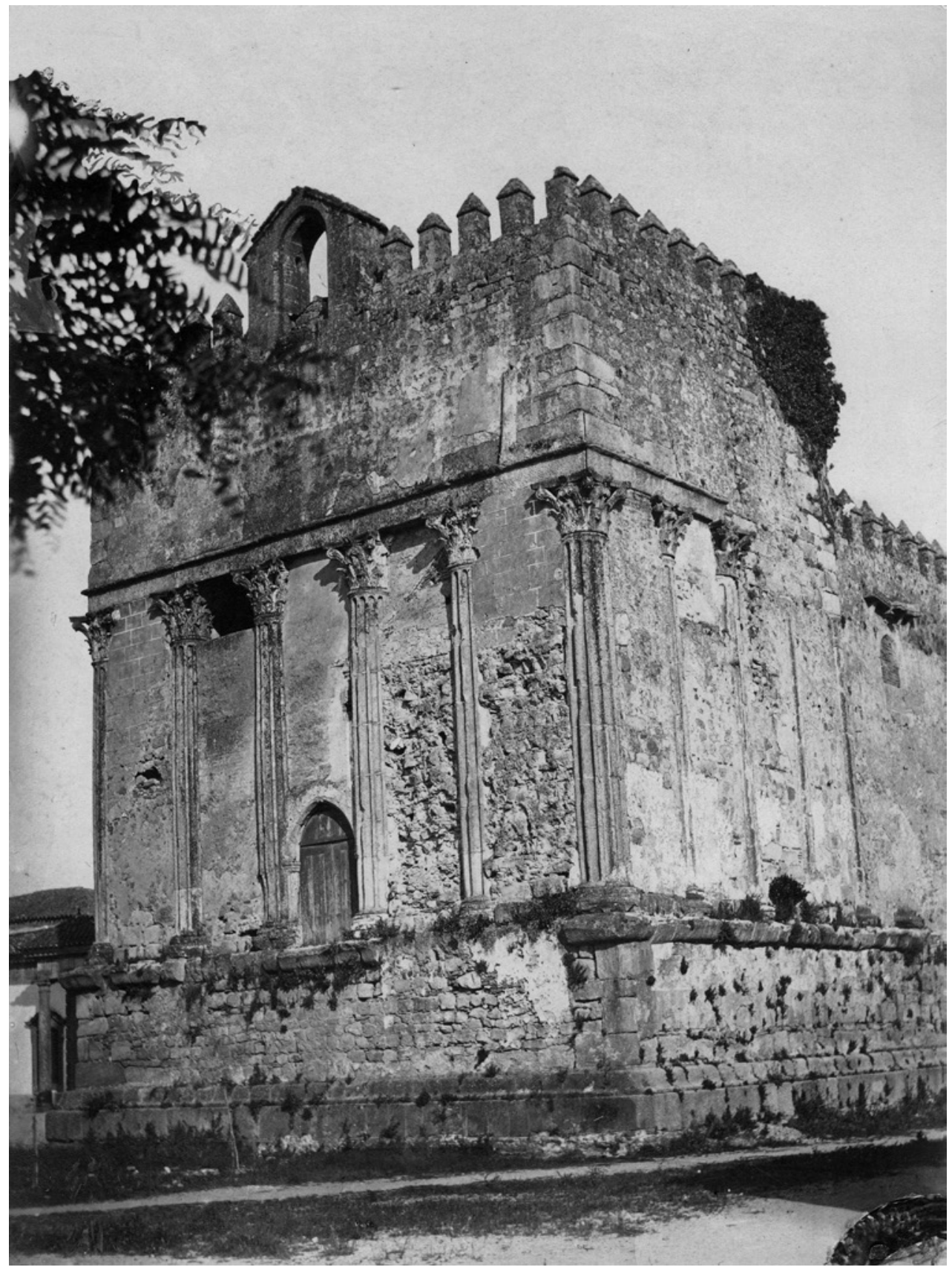

FIGURE 5.6 The Roman temple of Évora before restoration. Photo Pereira\&Prostes IMAGE (C) ARQUIVO FOTOGRÁFICO DA CÂMARA MUNICIPAL DE ÉVORA 
established a vast programme of administrative reforms that included the revision of the cartas de foral, the charts that established the rights and duties of every city in Portugal. Évora was one of the first to receive a new chart (1501), and it is possible that Bishop Afonso was behind the illuminated image that illustrates its first page. In it, Évora is presented using its Latin name - Ebvra Colonia Romana - and, to make this claim more effective, the typescript was manipulated to make it look somewhat more ancient, by graphing the ' $U$ ' (in 'Ebura') as a ' $\mathrm{V}$ ' and by inscribing the ' $\mathrm{O}$ ' (in 'colonia') within the ' $\mathrm{C}$. Whoever made these choices was certainly paying attention to inscriptions.

There is another aspect of the usage of Évora's Latin name which would have gone unnoticed to most, but certainly not to those who decided to use such a designation: Évora was never a colonia but simply a municipium whose correct name was actually Ebora Liberalitas Julia. This image and its caption thus show that the construction of a Roman past for Évora was already underway at the turn of the sixteenth century and that liberal inventions were not beyond acceptance by those who were invested in the endeavour.

In January 1531, a strong earthquake hit Lisbon, causing the court to take refuge in Évora, where it stayed until the end of the decade. Along with the king, John III (r. 1521-1557), came the resources and initiative of the country's aristocracy, the talent of its best artists, and the knowledge of its most prominent intellectuals. The king's chroniclers are unanimous in acknowledging the monarch's feeble command of Latin, but the stage was nonetheless set for Évora to become the capital of the Portuguese renaissance. ${ }^{25}$ The city's Roman past became, once again, a major concern.

It was in this context that Resende returned to his native city, where he became perhaps the most prominent humanist in the country. As mentioned before, he was also one of the Portuguese literati most engaged in the search for the country's Roman past. He thus devoted considerable efforts to identifying Roman inscriptions found in the region. He transcribed several that had been incorporated into the walls of later buildings, but in those years there were many active construction sites in Évora and master builders got into the habit of calling upon him whenever new materials surfaced. Resende quoted these abundantly in his books. He kept several of his findings for himself, in his own house, which makes it difficult to verify some of his claims today. A few of

25 The best analysis of Évora as a renaissance capital under John III remains the unpublished Moreira R., A Arquitectura do Renascimento no Sul de Portugal. A Encomenda Régia Entre o Moderno e o Romano, $\mathrm{PhD}$ dissertation (Lisbon: 1991). 
his findings can be identified and authenticated today; others, however, have been proven to be fakes, pure and simple. ${ }^{26}$

One of the inscriptions that has not survived and is known only through Resende's writings tells of the death of Lucius Sabinus, who fought in the war against the Lusitanians led by Viriato. According to Resende's testimony, the inscription uses expressions such as 'bellum contra Viriatum' (war against Viriato) or 'patria libera' (free fatherland), both of which are unlikely (to say the least) to have been used in their supposed context. ${ }^{27}$ In any case, the inscription reveals itself to be a fake beyond any doubt in using the word 'Lusitania', which was not created until over a century after Viriato's death. ${ }^{28}$ The inscription was evidently a fake, one of several that Resende created to support his claims.

It is in the third chapter of his Antiquities of Évora Resende wrote that the Roman general Sertorius had settled in Évora. His claim was based both on oral tradition and on an inscription that was lovingly preserved throughout the centuries in the Town Hall before it made its way to the city's museum. Today, opinions are divided about this inscription. Some claim it is a fake, while most are of the opinion that the 'Q. Sertori' it mentions is (or at least could just as well be) a different person. In any case, the inscription was found during the construction of a palace whose works did reveal the remains of a Roman construction. Such coincidences were enough for Resende to identify the site as that of Sertorius' ancient house in Évora, and for the count of Sortelha (who owned the construction site) to incorporate the findings into his new palace.

No other source even suggests that Sertorius ever visited, let alone lived in, Évora, but Resende's argument served everyone's interests well, and the square where the palace is located is still called Sertorius' Square. In renaissance Évora, it was important to prove that Sertorius had lived in the city. As mentioned before, Resende credited him with the construction of several pieces of urban infrastructure, including an aqueduct, which had since disappeared and which Resende was struggling to have restored.

Water supply was a major issue for all early modern cities, and all the more so for Évora, which had not been built by a river or any other abundant

26 Examples of inscriptions he kept in his house are mentionned in Resende, Obras Portuguesas 11, 24. On his fakes, see Encarnação J. d', "Da Invenção de Inscrições Romanas Pelo Humanista André de Resende", Biblos 67 (1991) 193-221.

27 Resende, Obras Portuguesas 14-15.

28 On the Roman administrative organization of Iberia, see Fabião C., "A romanização do actual território português", in Mattoso J. (ed.), História de Portugal, vol. 1: Antes de Portugal (Lisbon: 1992) 203-299. 
source of drinkable water. As the population of the city grew larger throughout the fifteenth century, the need for water became ever more pressing, and an attempt to resolve it through the construction of an aqueduct was first put forth by King John II (reg. 1481-1495), a project that was underway at the very end of the monarch's life. ${ }^{29}$ This project seems to have been abandoned under King Manuel (r. 1495-1521), who granted the use of the water obtained from whatever had been built of that aqueduct to Jorge da Silveira, a man from his council. Towards the end of his reign, Manuel himself spent over a year in Évora (1519-1521) and was therefore able to experience in person the problems water shortages were causing in the city. He thus decided to reactivate the construction of his predecessor's aqueduct, a desire that generated some legislation regarding 'the pipes that will be built' 30 but actually never were.

For King John III, Évora seems to have been an acquired taste. Immediately after the death of his father, all royal construction sites in the city (including the aqueduct) were halted, and they were not reactivated until a few years later, starting with the royal palace, which was amplified from 1525 on. It was not, however, until the following decade that the court settled in the city for a longer period, and in that context the practical and effective need of water became, once again, a priority. In the meantime, court culture, too, had changed; the influence of humanistic culture had become more prominent, and there was a growing general will to enrich the city with an ancient past and prestigious edifices that could testify to it. An aqueduct served all these needs perfectly: Vitruvius had written about them and nearby Merida (which Resende had visited and which was a rival in the quest for an ancient past) had a Roman one, and if Resende could convince his king that Sertorius had built one, then Évora, too, could claim the reconstruction of an original Roman aqueduct.

Oral tradition, which Resende uses as an argument to prove that a Roman aqueduct had indeed existed is, of course, unverifiable. More palpable are references to toponyms, the names of certain streets that had been used for as long as anyone could remember. For instance, there is Rua do Cano (Pipe Street), which today we can document as having had that name at least since 1290 and which, according to Resende, referenced a street where the old Roman aqueduct used to pass. Arcos do Divor (Arches of Divor) was another toponym

29 The history of the aqueduct before John III was best reconstructed by Bilou F., A Refundação do Aqueduto da Água da Prata em Évora, 1533-1537 (Lisbon: 2010), which I follow here.

30 'Os canos que se hão de fazer', mentioned in the document from December 1520 that appoints Fernão de Macedo as being responsible for the building site (cited in Bilou, A Refundação 48). 
that Resende evoked: Divor was the name of the source where water could be captured, and the arches referred to the structure that connected the source to the city. Furthermore, both street and road were located over a line where an aqueduct could, in fact, have been built most effectively. According to Resende, these toponyms preserved the memory of an aqueduct that had existed and since disappeared. At one point during his ramblings in and around Évora in search of ancient vestiges, Resende claimed to have identified the bases of two pillars of the Roman aqueduct. He so wanted to prove that there had indeed existed a Roman aqueduct that he took the king himself to see these archaeological findings, which are impossible to identify today.

An aqueduct such as this one was an expensive project, and the possibility of its construction generated much debate. For the purposes of this book it is especially important to note that Resende, its most prominent proponent, did not use the need for water as an important argument in its favour; for him, the really relevant issue at stake was the possibility of the reconstruction of Roman remains, especially one that was associated with a figure as prestigious as that of Sertorius. It is precisely on these issues that the discussion seems to have hinged in the sixteenth century. Resende's most significant opponent was Bishop D. Miguel da Silva, a close friend of the king ${ }^{31}$ who claimed that the Romans had never built an aqueduct in Évora and that Sertorius had never lived there either. Such opposition to Resende's cause justified his writing a text against the bishop's arguments and two further treatises on aqueducts, all of which have been lost and are only known because Resende mentions them in his writings. ${ }^{32}$ In all of them Resende evoked written sources, oral tradition, toponymy, and archaeology, as explained above. All these resources, however, did not prove sufficient to convince the various detractors of his claim, and most of all his king who hesitated on the matter.

It was in such context that a (supposedly) Roman inscription made its way into the discussion [Fig. 5.7]. According to this inscription, Sertorius had walled the city in honour of veteran soldiers who had become citizens of Évora:

31 Miguel da Silva and the king were close at that point in time; they would later quarrel and the bishop would flee the country to become a cardinal in Rome. On Bishop Miguel da Silva see Deswarte S., Il 'Perfetto Cortegiano' D. Miguel da Silva (Rome: 1989).

32 Resende himself refers to all these in Obras Portuguesas 44. For further discussion of this subject, see Deswarte, Il 'Perfetto Cortegiano' 84 ff.; and Rodrigues P.S., "A Muralha, o Templo e o Aqueduto Na Tradição de Sertório Construtor da Évora Romana (Séculos XVIXIX)", in Oliveira F. - Oliveira J. - Patrocínio M. (eds.), Espaços e Paisagens. Antiguidade Clássica e Heranças Contemporâneas (Coimbra: 2012) 255-263. 


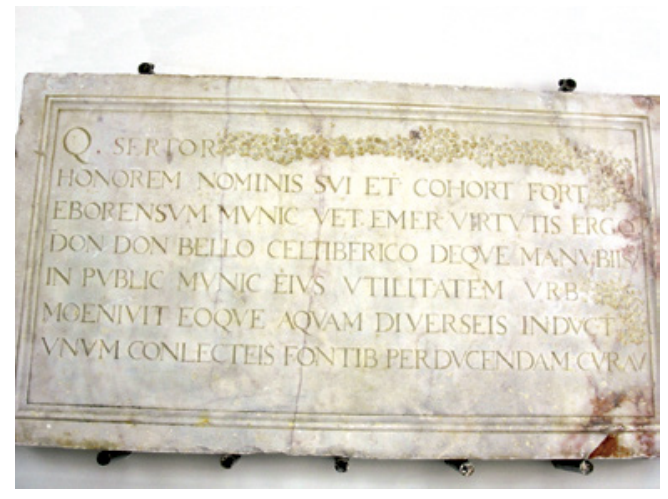

FIGURE 5.7

Inscription on the construction of Évora's aqueduct by Quintus Sertorius, Museu de Évora

IMAGE (C) NUNO SENOS

furthermore, the inscription tells us that Sertorius had built an aqueduct in order to supply the town with water:

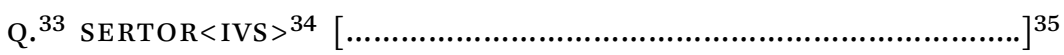

$<$ IN $>$ / HONOREM NOMINIS SVI ET COHORT $<$ IS $>{ }^{36} \mathrm{FORT}^{37} /$ EBORENSVM MVNIC. ${ }^{38}$ VET. $<$ ERANORUM $>39$ EMER. ${ }^{40}<$ ITORUM $>$ VIRTVTIS ERGO / DON DON ${ }^{41}$ BELLO CELTIBERICO DEQVE MANVBIIS / IN PVBLIC $<$ AM $>42$

33 =QVINTVS. I am grateful to Karl Enenkel for the annotation and the English translation of this inscription.

$34=$ SERTOR $<$ IVS $>$.

35 Here almost 80 per cent of the first line of the inscription has been deleted. It is not totally clear what text Resende (or the falsifier) supposed to have been deleted. In any event, the following 'HONOREM' requires an 'IN' just before it. Furthermore, the odd 'DON DON' suggests that a building or another kind of substantial present was meant.

36 It is obvious that, according to Resende (or the falsifier), соноRT.<IS $>$ should be read, the t.t. for a group of Roman army cavalry.

37 Resende must have had FORT $<$ IVM $>$ in mind.

38 Probably believed by Resende (or the falsifier) to be supplied as MVNIC<IPIUM $>$ (plural form of 'municeps'). However, 'MUNIC' is not a normal abbreviation in Roman epigraphy. 'MVNICIPIVM' would ususally have been abbreviated as 'MVN'.

39 Probably thought to be supplied as VET<ERANORUM $>$.

40 Obviously thought to be supplied as EMER $<$ ITORUM $>$.

41 The repetitve 'DON DON' is odd. 'D.D.' - which may mean D $<$ ONO $>$ D $<$ EDIT $>$ or D $<$ EDIT $>$ $\mathrm{D}<\mathrm{ONAVIT}>$ or $\mathrm{D}<\mathrm{ONO}>\mathrm{D}<\mathrm{ICAVIT}>-$ would be a normal and accepted abbreviation in Roman epigraphy. It is not entirely clear what Resende had in mind. Maybe it was something like 'DONVM DONAVIT'; however, this is tautological and not a correct formulation of Roman epigraphy either.

42 Obviously thought to be supplied as PVBLIC $<$ AM $>$. 'PVBLIC', however, is not a normal abbreviation in Roman epigraphy; PVBLICAM would have been abbreviated either as PVB or as PVBL. 
MVNIC $<$ IPII $>^{43}$ EIVS VTILITATEM VRB $<$ EM $>^{44} /$ MOENIVIT EOQUE AQVAM DIVERSEIS ${ }^{45}$ IN DVCT $<$ VM $>46 /$ VNVM COLLECTEIS F ONTIB $<$ VS $>47$ PERDVCENDAM CVRAV $<$ IT $>48$.

Quintus Sertorius, <in $>$ honor of his name and of that of the group of cavalry of brave veterans, citizens of the municipium of Évora, has do-

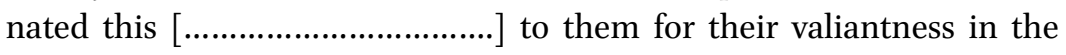
Celtiberian war, and has fortified the city with a wall built from the money that was obtained from the sale of the booty, for the public good of the municipium, and he took care that water was conducted to it by means of an aqueduct in which various springs had been brought together.

Resende mentions this inscription in chapter VI of his book ${ }^{49}$ and a full transcription is given in the fifth book of the Antiquities of Lusitania, added by Diogo Mendes de Vasconcelos to the unfinished manuscript left by Resende, which Vasconcelos published in a revised form in $1593 .{ }^{50}$ According to Vasconcelos, Bishop Miguel da Silva accused Resende of having faked this inscription, arguing that Sertorius was the Roman mother's surname, and not that of his father. The bishop's arguments, however, do not seem to have been considered seriously: prominent sixteenth-century authors, such as João de Barros and António de Castilho, echo Resende in praising the king for having restored a Roman monument ascribed to Sertorius.

It was not until the nineteenth century that epigraphy specialist Emil Hübner provided a critical analysis of Resende's work, exposing parts of it as either over-interpretations or, in the case of this particular inscription, fakes. ${ }^{51}$ Since Hübner's work, much has been written about Resende's historiographic work; that the inscription under analysis is a fake has become universally

43 Obviously thought to be supplied as MVNIC $<$ IPII $>$.

44 Obviously thought to be supplied as VRB $<\mathrm{EM}>$. However, it is an odd mistake by Resende (or the falsifier) to call a 'municipium' an 'urbs'. In Roman antiquity, 'urbs' was usually a privileged title of Rome.

45 'Diversis [...] collecteis fontibus' is odd and does not belong to the language of Roman epigraphy. The falsifier, however, has deliberately used the archaic forms 'diverseis' and 'collecteis' in order to give the inscription an authentic flavour.

46 Obviously thought to be supplied as DVCT $<\mathrm{VM}>$ (waterline).

47 Obviously thought to be supplied as FONTIB $<\mathrm{VS}>$.

48 Obviously thought to be supplied as CVRAV $<\mathrm{IT}>$.

49 Resende, Obras Portuguesas 50.

50 Resende, De antiquitatibus Lusitaniae, liber quintus 14.

$5^{1}$ Hübner E., Corpus Inscriptionum Latinarum vol. II (Berlin: 1869) 14. 


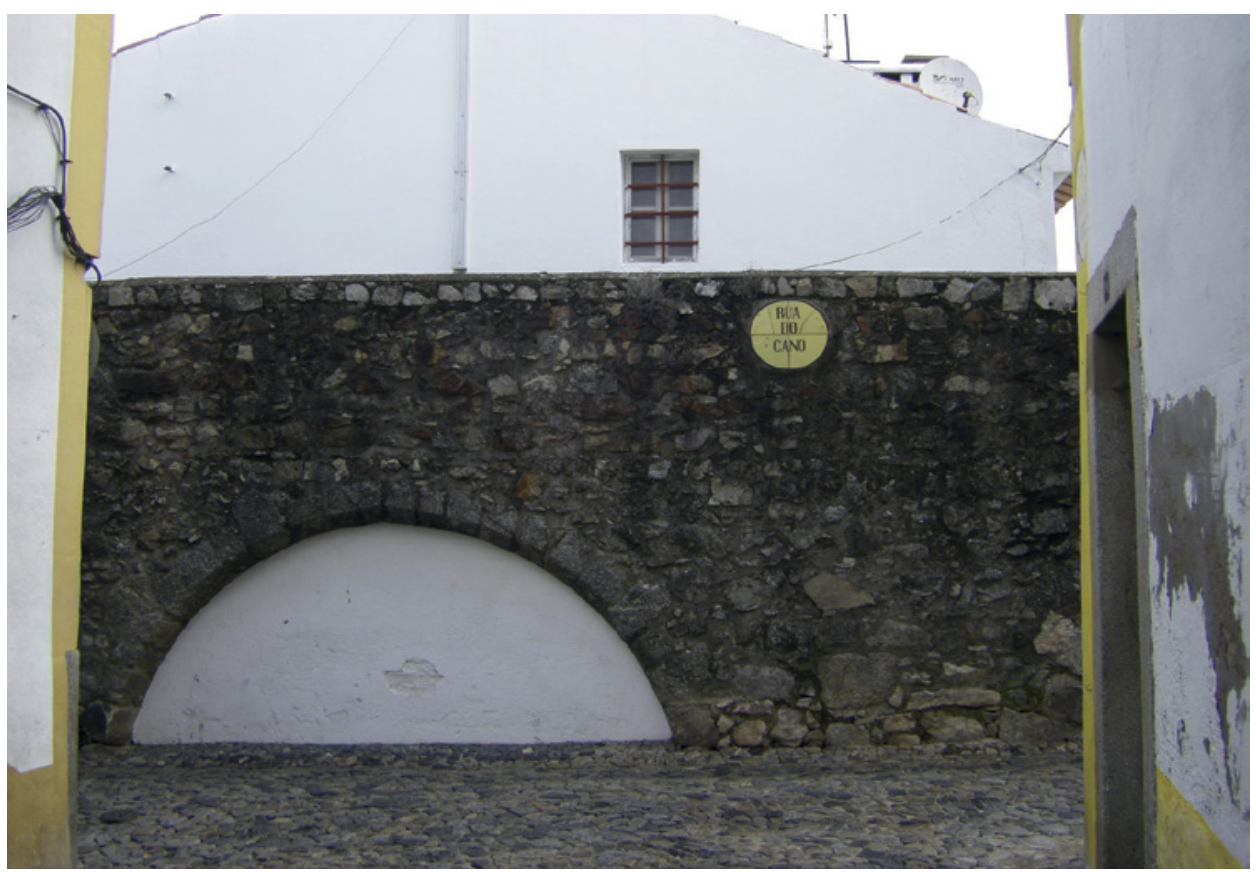

FIGURE 5.8 Section of the aqueduct of Água da Prata, Évora IMAGE (C) NUNO SENOS

accepted. ${ }^{52}$ The use of terms that were not common at the time or that did not exist, the odd use of abbreviations, and the fact that the part of the inscription that has been damaged does not seem to have ever had any text underneath all of these arguments have been used to disqualify it as an acceptable historical source.

Be that as it may, in the context of Resende's argument this inscription proved the existence of the city walls and of the aqueduct in Roman times, and it assigned both to the initiative of Sertorius. In a time when inscriptions functioned as the ultimate proof of historical probity, this one seems to have been a final and decisive argument. In 1534 work began on the (re)construction of this major structure crossing the fields from Divor to Évora, some $16 \mathrm{~km}$ long, following precisely the line that had been called, from time immemorial,

$5^{2}$ Cf. Pereira's critical remarks to Resende, Carta a Bartolomeu; Deswarte, Il Perfetto Cortegiano'; Encarnação, "Da Invenção"; Bilou, A Refundação; and Rodrigues, "A Muralha" $255^{-263 .}$ 
Arcos do Divor, Arches of Divor [Fig. 5.8]. Upon entering the city, the aqueduct followed the street that had always been called Rua do Cano, or Pipe Street; was punctuated at strategic points by reservoirs [Fig. 5.9]; and finally served its contents to the public through several fountains built throughout the city [Fig. 5.10]. Not only had Évora resolved its water supply problem, it could now also claim the possession of a major public work as useful and monumental as those of the Romans and genuinely based on a Roman precedent. King John III now had more solid grounds to claim for himself the status of Patris Patriae, as he proudly did on the façade of the church of Graça, which was being built at the same time, for his own burial..$^{53}$ The idea to use such a title on this façade may well have been Resende's.

Whether Resende was right or not about the Roman origins of the sixteenthcentury aqueduct remains under discussion. In the 1980s, archaeological campaigns proved that in Roman times water did indeed make it all the way to the highest points in the city: there was the rediscovery, in 1987, of the Roman thermae that have already been mentioned (and whose memory had been lost since the eighteenth century), and the discovery in 1989 of water tanks surrounding the Roman Temple.$^{54}$ Specialists agree that such structures could not have functioned without an abundant source of water provided by a structure such as an aqueduct. Even more recently, archaeologists seem to have found the remains of a Roman dam as well as some remnants that could correspond to the bases of the arches of an aqueduct, ${ }^{55}$ perhaps those Resende showed to his king back in the 1530s. In any case, it seems ever more likely that there was indeed once a Roman aqueduct that brought water from Divor to Évora, just like Resende claimed, even if he had to fake evidence to prove it, and even if Sertorius had nothing to do with it.

In conclusion, it can be said that for Resende, the appropriate past he was trying to construct for his city (and, by extension, his country) had to be simultaneously Roman and Christian. The Roman component brought the prestige that ancient times possessed for all humanists; the aqueduct served this purpose. At the same time, it was crucial to prove that Évora had been Christian from the dawn of Iberian Christianity, not only because in this context it was impossible to conceive identity outside of religion, but also because Resende wanted his city to be able to rival other old Christian centres of the Peninsula,

53 On this church see Branco M.C., A Construção da Graça de Évora. Contexto Cultural e Artístico, PhD dissertation (Lisbon: 1990).

54 Silva A.C., "A restauração do templo romano de Évora", A Cidade de Évora, 2nd series, 1 (1994-1995) 63-71.

55 Dias C., "Alicerces de Aqueduto Romano Descobertos em Évora", Público (1 November 2016). 


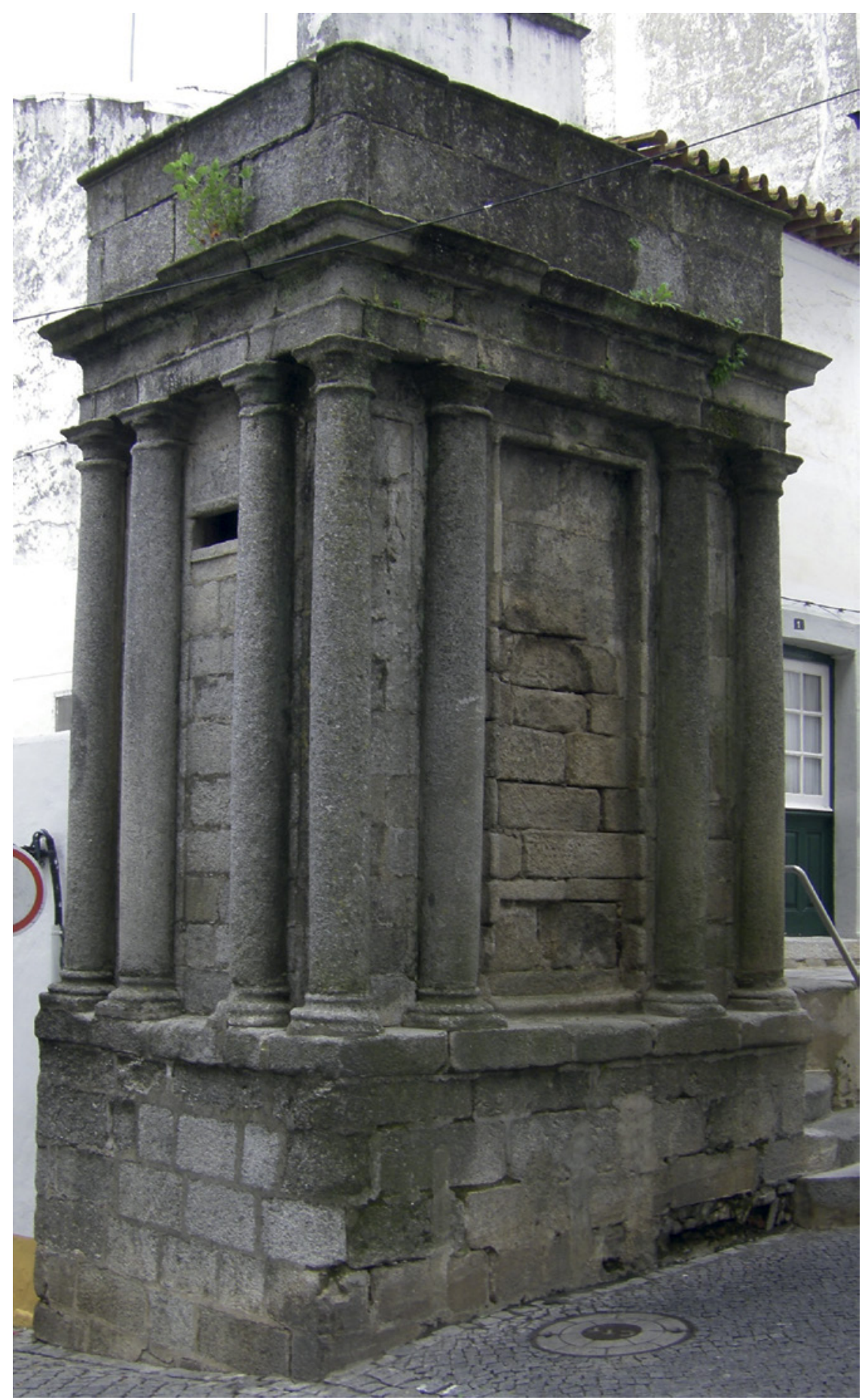

FIGURE 5.9 Water reservoir, part of the aqueduct of Água da Prata, Évora IMAGE ( ) NUNO SENOS 


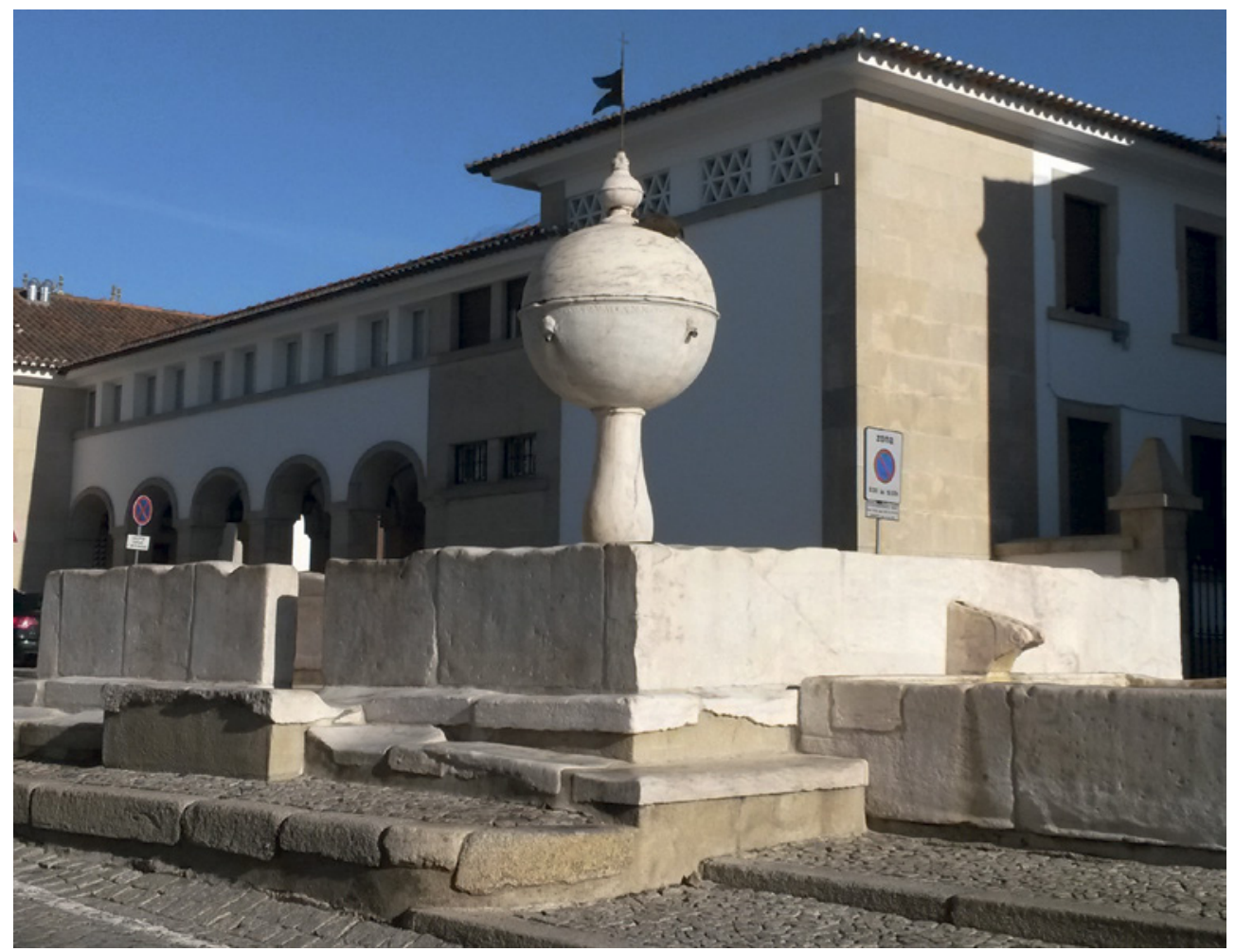

FIGURE 5.10 Water fountain (Chafariz das Portas de Moura), Évora (1556)

IMAGE (C) NUNO SENOS

such as Toledo. Finally, the ultimate goal of the search for both pasts was the creation of a solid national identity, which could require selecting heroes who fought against the Romans, relying on little more than local tradition to argue for Évora as the birthplace of certain saints, or, ultimately, faking inscriptions. A sense of local pride and patriotism justified it all.

\section{Bibliography}

Bilou F., A Refundação do Aqueduto da Água da Prata em Évora, 1533-1537 (Lisbon: 2010). Branco M.C., A Construção da Graça de Évora. Contexto Cultural e Artístico, PhD dissertation (Lisbon: 1990).

Branco M., "Renascimento, Maneirismo e Estilo Chão em Évora", in Cunha M.S. da (ed.), Do Mundo Antigo aos Novos Mundos. Humanismo, Classicismo e Notícias dos Descobrimentos em Évora (1516-1624) (Lisbon: 1998) 219-247. 
Caetano J.O., "Sombras e Alguma Luz Sobre o Bispo D. Afonso de Portugal", Cenáculo. Boletim On Line do Museu de Évora 2 (2007) 3-24.

Deswarte S., Il 'Perfetto Cortegiano' D. Miguel da Silva (Rome: 1989).

Dias C., "Alicerces de Aqueduto Romano Descobertos em Évora", Público (1 November 2016), accessible online at https:/www.publico.pt/2016/11/o1/local/noticia/ali cerces-de-aqueduto-romano-descobertos-em-evora-1749565 (retrieved 23 November 2017).

Encarnação J. d', "Da Invenção de Inscrições Romanas Pelo Humanista André de Resende", Biblos 67 (1991) 193-221.

Espanca T., Évora (Lisbon: 1993).

Espanca T., "Fundação e Evolução Histórica da Igreja dos Mártires de Évora", A Cidade de Évora, 1st series, 29-30 (1949) 472-483.

Ferreira F.L., "Notícias da vida de André de Resende", Arquivo Histórico Português 7 (1909) 393-417; 8 (1910) 62-69, 161-184, 338-366; 9 (1914) 177-334.

Hübner E., Corpus Inscriptionum Latinarum (Berlin: 1869).

Leal J.C., Giuseppe Cinatti (1808-1879). Percurso e Obra, MA thesis (Lisbon: 1996).

Moreira R., A Arquitectura do Renascimento no Sul de Portugal. A Encomenda Régia Entre o Moderno e o Romano, $\mathrm{PhD}$ dissertation (Lisbon: 1991).

Resende André de, As antiguidades da Lusitânia, ed. R.M. Rosado Fernandes (Lisbon: 1996).

Resende André de, Carta a Bartolomeu de Quevedo, ed. V.S. Pereira (Coimbra: 1988).

Resende André de, De antiquitatibus Lusitaniae (Évora, Martim de Burgos: 1593).

Resende André de, História da antiguidade da cidade de Évora (Évora, André de Burgos: 1553).

Resende André de, Obras Portuguesas, ed. J.P. Tavares (Lisbon: 1963).

Resende André de, Oração de sapiência (Oratio pro Rostris), ed. A. Moreira de Sá (Lisbon: 1956).

Rodrigues P.S., "A Muralha, o Templo e o Aqueduto Na Tradição de Sertório Construtor da Évora Romana (Séculos XVI-XIX)”, in Oliveira F. - Oliveira J. - Patrocínio M. (eds.), Espaços e Paisagens. Antiguidade Clássica e Heranças Contemporâneas (Coimbra: 2012) $255^{-263 .}$

Silva A.C., "A restauração do templo romano de Évora", A Cidade de Évora, 2nd series, 1 (1994-1995) 63-71. 